\title{
30. TRACE ELEMENT AND SR-ISOTOPIC CONTENTS OF HYDROTHERMAL CLAYS AND SULFIDES FROM THE SNAKE PIT HYDROTHERMAL FIELD: ODP SITE 6491
}

\author{
Kathryn M. Gillis, ${ }^{2,3}$ Alan D. Smith, ${ }^{2}$ and John N. Ludden ${ }^{2}$
}

\begin{abstract}
Several meters of unconsolidated hydrothermal sediment were recovered from the Snake Pit hydrothermal field during ODP Leg 106. Polymetallic sulfides comprise most of the sediment with minor fragments of massive sulfide, organic debris, clay minerals, and fresh glass shards. Trace element and $\mathrm{Sr}$-isotope contents of hydrothermal clays and sulfides from Holes $649 \mathrm{~B}$ and $649 \mathrm{G}$ indicate that these minerals precipitated from a mixed hydrothermal fluid-seawater solution. Evaluation of the REE mineral data and the Snake Pit hydrothermal fluids shows that the REE distribution coefficients between the hydrothermal fluids and clay-sulfide mixes range from 100-500. This indicates that hydrothermal fluids originating in the root-zone of the Snake Pit hydrothermal system may be modified by the precipitation of hydrothermal minerals, either in the shallow subsurface or within chimney structures. Contrasting REE profiles of clay-sulfide aggregates and massive sulfides from Holes 649B and 649G may be accounted for by spatial and/or temporal variations in redox conditions in the plumbing system.
\end{abstract}

\section{INTRODUCTION}

High-temperature hydrothermal fluids from vent fields along the East Pacific Rise, the Juan de Fuca ridge, and the Mid-Atlantic ridge (Edmond et al., 1979; Von Damm et al., 1985; Von Damm and Bischoff, 1987; Campbell et al., 1988) show similarities in major ion components (Von Damm, 1988); however, each vent field has a distinct composition (Bowers et al., 1988). The composition of these fluids is believed to be buffered at depth by greenschist facies mineral assemblages, presumably adjacent to, or above, a magma chamber (Bowers et al., 1988). Regional differences in composition are attributed to factors such as the depth of reaction and/or variation in the secondary mineral assemblage (Seyfried, 1987; Bowers et al., 1988).

During the initial stage of chimney formation, anhydrite and sulfides precipitate from mixed hydrothermal fluid-seawater solutions (Goldfarb et al., 1983; Haymon, 1983). As a system becomes mature, reaction within chimneys becomes restricted to minor chalcopyrite precipitation along inner chimney walls and hydrothermal fluids pass through chimney structures with little or no modification (Woodruff and Shanks, 1988). Variable S-isotopic contents in hydrothermal fluids between different vent sites at $21^{\circ} \mathrm{N}$, East Pacific Rise, show that hydrothermal fluids venting from chimneys have a seawater component which implies that hydrothermal fluids ascending from depth mixed with seawater somewhere in the plumbing system (Woodruff and Shanks, 1988). Moreover, the paragenesis and composition of sulfides, sulfates, and silicates associated with individual vent fields indicate that temperatures and fluid compositions fluctuate both spatially and temporally (Styrt et al., 1981; Janecky and Seyfried, 1984; Honnorez et al., 1985; Tivey and Delaney, 1986).

An active high-temperature hydrothermal field was discovered at $23^{\circ} 22^{\prime} \mathrm{N}$ in the Mid-Atlantic rift valley during Leg 106

\footnotetext{
${ }^{1}$ Detrick, R., Honnorez, J., Bryan, W. B., Juteau, T., et al., 1990. Proc. ODP, Sci. Results, 106/109: College Station, TX (Ocean Drilling Program).

2 Département de Géologie, Université de Montréal, C.P. 6128, Succursale A, Montréal, Quebec, Canada $\mathrm{H} 3 \mathrm{C} 3 \mathrm{~J} 7$.

${ }^{3}$ Present address: Woods Hole Oceanographic Institution, Woods Hole, MA 02543.
}

of the Ocean Drilling Program (ODP). We have analyzed hydrothermal clay minerals and sulfides recovered at Site 649 for trace and rare earth elements (REE) and $\mathrm{Sr}$ isotopes. The purpose of our study was to evaluate the relative contribution of hydrothermal fluids and seawater in the solution precipitating the hydrothermal minerals and to predict how the precipitation of these phases would modify the composition of hydrothermal fluids. Our results, when compared to the compositions of vent fluids collected during an Alvin dive in May 1986 (Campbell et al., 1988), indicate that the minerals precipitated from a mixed seawater-hydrothermal fluid solution, whose alkali and REE composition was dominated by seawater and hydrothermal fluid, respectively.

\section{GEOLOGIC SETTING}

The Snake Pit hydrothermal field (Site 649) covers an area of approximately $20,000 \mathrm{~m}^{2}$ on a small terrace near the top of a large volcanic ridge. Hydrothermal activity is restricted to ridge-shaped structures that parallel the northeast-trending Snake Pit fissure (Shipboard Scientific Party, 1988; Thompson et al., 1988). Ten holes were drilled in the hydrothermal sediment surrounding the easternmost ridge during Leg 106. The vents along this ridge were actively discharging solutions with temperatures of $335^{\circ}-350^{\circ} \mathrm{C}$ (Campbell et al., 1988; Thompson et al., 1988). Hydrothermal sediment, recovered at Hole 649B, varies in size from medium- to coarse-grained silt to angular fragments up to a few centimeters in length. Black, friable $\mathrm{Fe}$ and $\mathrm{Fe}$ - $\mathrm{Cu}$ sulfides comprise $>\mathbf{9 0 \%}$ of the sediment; the remainder is composed of minor brassy $\mathrm{Cu}-\mathrm{Fe}$ sulfide fragments, talc-sulfide aggregates, organic debris, and a few fresh glass shards (Shipboard Scientific Party, 1988). Three massive sulfide fragments and one clay-rich fragment were recovered at Hole 649G.

\section{ANALYTICAL METHODS}

Three talc-sulfide aggregates and one sulfide sample were analyzed for trace element, REE, and $\mathrm{Sr}$-isotopic content. Two talc-sulfide aggregates selected from Hole 649B are representative of the hydrothermal sediment. The massive sulfide and clay-rich samples from Hole 649G were the only samples available for analysis. The mineralogy of each sample, identified by X-ray diffraction, is given in Table 1 . The 
Table 1. Mineralogy of samples.

\begin{tabular}{lccccc}
\hline & Talc & Chal & Sphal & Pyr & Marc \\
\hline 106-649B-ID-2, 0-60 cm & $\mathrm{X}$ & $\mathrm{X}$ & $\mathrm{X}$ & $\mathrm{X}$ & $\mathrm{X}$ \\
106-649B-ID-8, 120-150 cm & $\mathrm{X}$ & $\mathrm{X}$ & $\mathrm{X}$ & $\mathrm{X}$ & $\mathrm{X}$ \\
106-649G-ID-1, piece 5 & $\mathrm{X}$ & $\mathrm{X}$ & & & \\
106-649G-ID-1, piece 4 & & $\mathrm{X}$ & $\mathrm{X}$ & $\mathrm{X}$ & \\
\hline
\end{tabular}

Summarized from Shipboard Scientific Party (1988). Abbreviations: Chal $=$ chalcopyrite $;$ sphal $=$ sphalerite $;$ pyr $=$ pyrite $;$ marc $=$ marcasite.

small size of the samples prevented the physical separation of the clay-minerals from the polymetallic sulfides. Prior to dissolution, all samples were crushed to approximately 200 $\mu \mathrm{m}$. The clay-rich samples were hand-picked to remove grains of Fe-hydroxides and to concentrate the clay fraction.

$\mathrm{K}, \mathrm{Rb}, \mathrm{Sr}, \mathrm{Sm}$, and $\mathrm{Nd}$ contents and ${ }^{87} \mathrm{Sr} /{ }^{86} \mathrm{Sr}$ ratios were measured by isotope dilution (IDMS) using a modified NBS 12 -in. radius mass spectrometer at the Université de Montréal following the method of Machado et al. (1986). ${ }^{87} \mathrm{Sr} /{ }^{86} \mathrm{Sr}$ ratios are normalized to ${ }^{86} \mathrm{Sr} /{ }^{88} \mathrm{Sr}=0.1194$ and 0.70800 for the $\mathrm{E} \& \mathrm{~A}$ standard. Blanks measured during this study were: $\mathrm{Sr}, 940 \mathrm{pg}$; $\mathrm{Rb}, 27 \mathrm{pg}$; K, $10 \mathrm{ng}$; Sm, 12 pg; and Nd, $260 \mathrm{pg}$.

REE were determined using a combined pre-irradiation group separation neutron activation-isotope dilution technique modified from Duke and Smith (1987): the coherence of the REE group during isotope dilution chemistry allows the removal of a REE-rich aliquot prior to the first ion exchange column stage. This aliquot is loaded onto a cation column where the REE group is isolated following elution with $0.1 \mathrm{M}$ oxalic $-1.0 \mathrm{M} \mathrm{HCl}$ and $2 \mathrm{M}$ $\mathrm{HNO}_{3}$ acids to remove $\mathrm{Fe}, \mathrm{Sc}$, the alkalis, and alkaline earths. After evaporation to dryness, the REE concentrates were irradiated at a flux of $1 \times 10^{12} \mathrm{n} \mathrm{cm}^{-2} \mathrm{~s}^{-1}$ in a SLOWPOKE II nuclear reactor to determine the abundances relative to $\mathrm{Sm}$. Counting was performed using a coaxial Ge detector (resolution $0.9 \mathrm{keV}$ at $122 \mathrm{keV}$ ) coupled to a CANBERRA Series 8OMCA. After a decay period of $4 \mathrm{hr}$, counting for $2 \mathrm{hr}$ allowed the determination of Sm, Eu, Dy, and Ho. A second, 12-hr count after 24-36 hr allowed the determination of $\mathrm{La}, \mathrm{Sm}, \mathrm{Eu}$, and $\mathrm{Yb}$. After correction for the amount of spike $\mathrm{Sm}$, the relative REE abundances were corrected for yield to their absolute abundances by normalization to the $\mathrm{Sm}(\mathrm{IDMS}) / \mathrm{Sm}$ (NAA) ratio. Detection limits are listed in Table 3 . Precision based on counting statistics is: $\mathrm{La}>0.1 \mathrm{ppm} 3 \%, 0.1-0.01 \mathrm{ppm} 3 \%-15 \%,<0.01$ ppm 20\%; Sm, Eu, and Dy 1\%-3\%; Ho <10\%; and Yb 20\%. The chemical extraction procedures remove all Th and $\mathrm{U}$ making overlap corrections for their fission products unnecessary. Blanks for the REE were below the detection limits given in Table 3.

\section{RESULTS \\ $\mathbf{K} / \mathbf{R b}, \mathrm{Sr} / \mathbf{R b}$, and ${ }^{87} \mathrm{Sr} /{ }^{86} \mathrm{Sr}$ ratios}

Two talc-sulfide samples (106-649B-ID-2, 0-60 cm, and 106-649G-1D-1, piece 5) have $\mathrm{K} / \mathrm{Rb}, \mathrm{Sr} / \mathrm{Rb}$, and ${ }^{87} \mathrm{Sr} /{ }^{86} \mathrm{Sr}$ ratios (Table 2) intermediate between seawater (Bruland, 1983; Palmer and Elderfield, 1985) and the Snake Pit fluids (Campbell et al., 1988). Mixing calculations indicate that these talc-sulfide samples precipitated from a seawater-dominated solution with 3\%-12\% hydrothermal fluid (106-649B-ID-2, 0-60 cm, and 106-649G-1D-1, piece 5, respectively). In contrast, the $\mathrm{K} / \mathrm{Rb}$ and $\mathrm{Sr} / \mathrm{Rb}$ ratios of the third talc-sulfide sample (106-649B-ID-8, 120-150 cm) are significantly lower than both seawater and the hydrothermal fluid. $\mathrm{K} / \mathrm{Rb}$ and $\mathrm{Sr} / \mathrm{Rb}$ ratios of low-temperature clay minerals recovered from the shallow oceanic crust are generally lower than seawater and the host basalt due to preferential uptake of $\mathrm{Rb}$ over $\mathrm{K}$ into the interlayer position (Staudigel et al., 1981). Similar low-temperature clays have been identified at the Snake Pit Site (A. Adamson, pers. comm., 1988). Inclusion in the talc-sulfide aggregate could produce the lower alkali ratios in this sample. The $\mathrm{K} / \mathrm{Rb}$ ratio of the sulfide sample (106-649G-ID-1, piece 4) is lower than seawater and slightly higher than the hydrothermal fluid (Table 2).

The Sr content of the Hole 649G sulfide is significantly lower than sulfides from the East Pacific Rise (Vidal and Clauer, 1981). This may reflect the lower Sr content of the Snake Pit fluids relative to the East Pacific Rise fluids (Campbell et al., 1988) and/or different proportions of seawater and hydrothermal fluid in the precipitating solution. The latter interpretation is supported by leaching experiments of the East Pacific Rise sulfides which indicate that their wide range in $\mathrm{Sr}$ contents and ${ }^{87} \mathrm{Sr} /{ }^{86} \mathrm{Sr}$ ratios are due to precipitation from solutions with varying proportions of seawater and hydrothermal fluids (Vidal and Clauer, 1981).

\section{REE Contents}

Deep Atlantic seawater is LREE enriched with a large negative Ce anomaly, flat MREE, and slightly enriched HREE (Fig. 1; De Baar et al., 1983). The Snake Pit hydrothermal fluids are also LREE enriched with large positive Eu anomalies and depleted HREE (Fig. 1; Campbell et al., 1988). The LREE concentrations range from 30 to 90 times that of

Table 2. Trace element contents (ppm), and ${ }^{87} \mathrm{Sr} /{ }^{86} \mathrm{Sr}$ ratios of hydrothermal clays, sulfides, Snake Pit hydrothermal fluids, and seawater.

\begin{tabular}{|c|c|c|c|c|c|c|}
\hline Sample No. & $\underset{(\mathrm{ppm})}{\mathrm{Sr}}$ & $\underset{(\mathrm{ppm})}{\mathrm{Rb}}$ & $\underset{(\mathrm{ppm})}{\mathrm{K}}$ & $\mathrm{K} / \mathrm{Rb}$ & $\mathrm{Sr} / \mathrm{Rb}$ & ${ }^{87} \mathrm{Sr} /{ }^{86} \mathrm{Sr}$ \\
\hline $\begin{array}{l}\text { 106-649B-1D-2, 0-60 cm } \\
\text { (talc-sulfide mix) }\end{array}$ & 4.72 & 0.220 & 494 & 2245 & 21.4 & $0.70898 \pm 3$ \\
\hline $\begin{array}{l}\text { 106-649B-1D-8, 120-150 cm } \\
\text { (talc-sulfide mix) }\end{array}$ & 4.45 & 6.66 & 1120 & 168 & 0.668 & n.d. \\
\hline $\begin{array}{l}\text { 106-649G-1D-1, } 23-25 \mathrm{~cm} \text {, } \\
\text { piece } 5 \text { (talc-chalcopyrite } \\
\text { mix) }\end{array}$ & 5.90 & 0.130 & 371 & 2854 & 45.4 & $0.70844 \pm 3$ \\
\hline $\begin{array}{l}\text { 106-649G-1D-1, piece } 3 \\
\text { (massive sulfide) }\end{array}$ & 0.24 & 0.021 & - & - & 111 & n.d. \\
\hline Hydrothermal fluid ${ }^{\mathrm{a}}$ & 4.42 & 0.91 & 931 & 1023 & 4.9 & 0.7028 \\
\hline Seawater ${ }^{b}$ & 7.89 & 0.12 & 399 & 3323 & 65.8 & 0.7091 \\
\hline
\end{tabular}

\footnotetext{
${ }^{a}$ Hydrothermal fluid data from Campbell et al. (1988)

b Seawater concentrations from Bruland (1983). ${ }^{87} \mathrm{Sr} /{ }^{86} \mathrm{Sr}$ ratio from Hess et al. (1986),

n.d. $=$ not detected.

$-=$ not determined.
} 


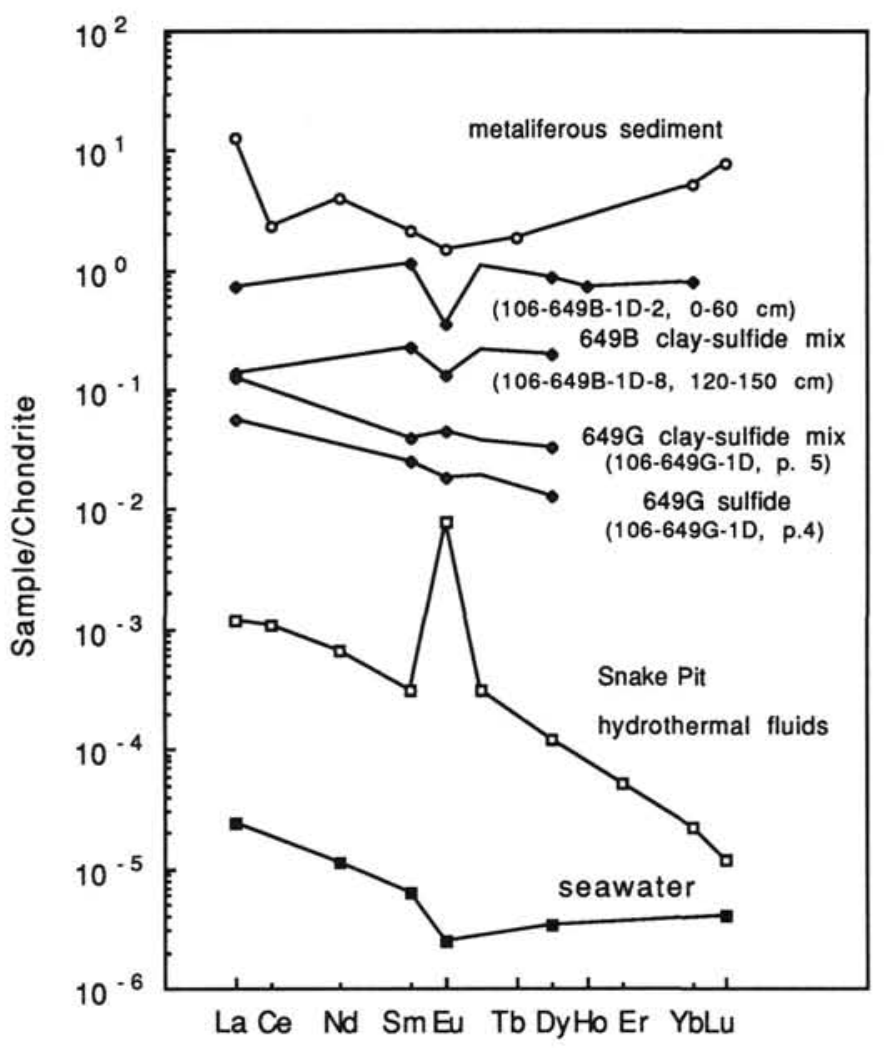

Figure 1. Chondrite normalized REE contents of hydrothermal clay minerals and sulfides from the Snake Pit hydrothermal field, the Snake Pit fluids (Campbell et al., 1988), North Atlantic bottom seawater (De Baar et al., 1983), and an average metalliferous sediment from the FAMOUS area (Bonnot-Courtois, 1981).

seawater; Lu concentrations are 2-5 times seawater (Campbell et al., 1988). Mixed seawater-hydrothermal fluid solutions should, therefore, be enriched in REE relative to seawater.

The $(\mathrm{La} / \mathrm{Sm})_{\mathrm{N}}$ ratios of the sulfide and talc-sulfide sample from Site 649G (Table 3) are similar to the hydrothermal fluid, whereas the $(\mathrm{La} / \mathrm{Dy})_{\mathrm{N}}$ ratios are lower. The abundance of REE in the samples is enriched by factors of 27 and 64, respectively (Fig. 1). The sulfide sample has a small negative $\mathrm{Eu}$ anomaly whereas the talc-sulfide sample has a small positive Eu anomaly. The clay component of the clay-sulfide sample apparently has a greater capacity to accommodate REE, in particular Eu, than the sulfide.

The talc-sulfide samples from Hole 649B have relatively flat REE patterns with $(\mathrm{La} / \mathrm{Sm})_{\mathrm{N}}$ ratios between 0.6 and 0.7 and negative Eu anomalies (Fig. 1; Table 3). La concentrations are 60-300 times the hydrothermal fluid; the $\mathrm{Yb}$ concentration of sample $106-649 \mathrm{~B}-\mathrm{ID}-2,0-60 \mathrm{~cm}$, is 85,000 times the hydrothermal fluid.

\section{DISCUSSION}

The trace element, REE, and isotopic content of hydrothermal fluids reflect the composition of phases that are dissolved and precipitated during fluid-rock interaction in both the root-zones of hydrothermal systems (Berndt et al., 1988) and in the shallow subsurface (Fig. 1). The similarity between hydrothermal fluid REE profiles and phenocryst/matrix partition coefficients of igneous plagioclase has led to the suggestion that REE released during alteration of plagioclase dominate the hydrothermal fluids (Campbell et al., 1988). It has also been proposed that precipitation of secondary minerals from a fluid with REE abundances comparable to the whole rock could fractionate the REE to produce the REE profile of the hydrothermal fluids sampled at surface (Michard et al., 1983). In both models the large Eu anomalies of the hydrothermal fluids are attributed to the reduction and mobilization of Eu from rocks that have reacted with hydrothermal fluids (Bence and Taylor, 1985), presumably in the root-zones of the hydrothermal system (Michard et al., 1983). The buffering effect of phases precipitated in the near surface environment or chimney structures on the REE composition of the hydrothermal fluid must also be evaluated to constrain processes occurring at depth. For example, comparison of the Site 649G sulfide fragment with the Snake Pit fluids (Fig. 1) implies that the fluid that precipitated the sulfide was less Eu enriched and more HREE enriched than the venting solution. Furthermore, calculated distribution coefficients for the sulfide and talcsulfide/hydrothermal fluid, ranging from 100 to 500 , indicate that precipitation of $<1 \%$ by volume of these phases would have a significant effect on the abundance of REE in the hydrothermal fluid. To further evaluate the REE budget of hydrothermal systems, we need to determine if hydrothermal fluids that react in the shallow subsurface and percolate through rubble piles contribute to hydrothermal fluids venting from chimney structures or if they are isolated from the main discharge zone.

The REE profiles of sulfides from the East Pacific Rise at $21^{\circ} \mathrm{N}$ (Bence, 1983) are comparable to those of the hydrothermal fluids from the same sites, particularly in their large positive Eu anomalies (Michard et al., 1983; Michard and Albaréde, 1986). The Snake Pit sulfide and ore from some volcanogenic massive sulfide deposits, such as the Que River deposit, Tasmania (Whitford et al., 1988), contrast with the East Pacific Rise deposits in showing no positive Eu anomalies. Such variation in the behavior of Eu between different hydrothermal sites may reflect differences in redox conditions at the time of precipitation (Sverjensky, 1984).

The REE content of the Hole $649 \mathrm{G}$ talc-sulfide and sulfide samples are similar to the Snake Pit fluid with the exception of Eu. In contrast, the REE patterns of the Hole 649B talcsulfide aggregates imply precipitation from a fluid depleted in LREE and Eu and enriched in HREE relative to the hydrothermal fluid. Several factors could contribute to their contrasting patterns. Precipitation of a phase that concentrates and fractionates these elements prior to the precipitation of the Hole 649B samples. The only phases identified at Site 649 other than sulfides and clay minerals are Fe oxyhydroxides, anhydrite, and opal (Ocean Drilling Program Leg 106 Scientific Party, 1986; Thompson et al., 1988). Iron oxyhydroxides associated with hydrothermal deposits are typically enriched in REE; however, their patterns are generally parallel to seawater (Fig. 1; Fleet, 1983). REE profiles of hydrothermal anhydrite from porphyry copper deposits show that LREE are preferentially incorporated into the anhydrite structure (Morgan and Wandless, 1980); however, the importance of anhydrite precipitation at the Snake Pit must still be evaluated. Quartz, with low abundances of REE (Rossman et al., 1987), would not significantly alter the REE composition of the hydrothermal fluid. Consequently, it is unlikely that these minor phases fractionated the fluid. Changes in redox conditions in the plumbing system of the Snake Pit could produce the contrasting REE profiles. For example, thermochemical data predict that divalent $\mathrm{Eu}$ dominates hydrothermal solutions at temperatures greater than $250^{\circ} \mathrm{C}$, whereas at lower temperatures, the oxidation state of Eu is dependent upon $\mathrm{pH}$ and the activities of potential ligands as well as temperature (Sverjensky, 1984). Thus, the minerals from each hole could have precipitated either from the same fluid but at a different 
Table 3. REE contents of hydrothermal clays and sulfides.

\begin{tabular}{lccccccc}
\hline \multicolumn{1}{c}{ Sample no. } & $\begin{array}{c}\mathrm{La} \\
(\mathrm{ppb})\end{array}$ & $\begin{array}{c}\mathrm{Sm} \\
(\mathrm{ppb})\end{array}$ & $\begin{array}{c}\mathrm{Eu} \\
(\mathrm{ppb})\end{array}$ & $\begin{array}{c}\mathrm{Dy} \\
(\mathrm{ppb})\end{array}$ & $\begin{array}{c}\mathrm{Ho} \\
(\mathrm{ppb})\end{array}$ & $\begin{array}{c}\mathrm{Yb} \\
(\mathrm{ppb})\end{array}$ & $(\mathrm{La} / \mathrm{Sm})_{\mathrm{N}}$ \\
\hline $\begin{array}{l}106-649 \mathrm{~B}-1 \mathrm{D}-2,0-60 \mathrm{~cm} \\
\text { (talc-sulfide mix) }\end{array}$ & 230 & 213 & 25.0 & 284 & 52.5 & 167 & 0.658 \\
$\begin{array}{l}106-649 \mathrm{~B}-1 \mathrm{D}-8,120-150 \mathrm{~cm} \\
\text { (talc-sulfide mix) }\end{array}$ & 44.0 & 42.9 & 9.54 & 62.9 & n.d. & n.d. & 0.625 \\
$\begin{array}{l}106-649 \mathrm{G}-1 \mathrm{D}-1, \text { piece } 4 \\
\text { (talc-chalcopyrite mix) }\end{array}$ & 40.3 & 7.64 & 3.17 & 10.6 & n.d. & n.d. & 3.21 \\
$\begin{array}{l}106-649 \mathrm{G}-1 \mathrm{D}-1,23-26 \mathrm{~cm}, \\
\text { piece 5 (massive sulfides) }\end{array}$ & 17.4 & 4.78 & 1.30 & 4.20 & n.d. & n.d. & 2.21 \\
\begin{tabular}{l} 
Detection limits \\
\hline
\end{tabular} & 2.3 & 2.4 & 0.12 & 0.90 & 0.22 & 1.4 & \\
\hline
\end{tabular}

n.d. $=$ not detected.

stage of its evolution, or from a different fluid. The differing mineralogy reflected in the presence of both high- and lowtemperature sulfides at Hole 649B and only high-temperature sulfides at Hole 649G suggests that the Hole 649B samples precipitated from a fluid with a greater seawater-component, as indicated by their ${ }^{87} \mathrm{Sr} /{ }^{86} \mathrm{Sr}$ ratios, and/or that the samples have undergone retrograde weathering or reworking or both.

Further trace element, REE, and isotopic studies of hydrothermal mineral separates from the Snake Pit and other hydrothermal sites are in progress. The subtle variation in the composition of hydrothermal fluids within, and between, vent fields provides important insight into the interpretation of the vent fluid data that must reflect both deep-seated and shallow subsurface processes.

\section{ACKNOWLEDGMENTS}

Research was funded by grants from the Natural Science and Engineering Research Council (NSERC) to J.N.L., and K.M.G. was supported by a NSERC postdoctoral fellowship. G. Gauthier, C. Gagner, and M. Boily are thanked for their help in the lab. Sample irradiation was performed at the Ecole Polytechnique by G. Kennedy and J. St. Pierre. A. Campbell and G. Thompson are gratefully acknowledged for providing preprints of their Snake Pit papers. This work benefited greatly from discussions with M. K. Tivey and members of the Leg 106 scientific party. A. Campbell, J. Honnorez, and M. Mottl are thanked for their helpful reviews.

\section{REFERENCES}

Bence, A. E., 1983. Volcanogenetic massive sulfides: Rock/water interactions in basaltic systems and their effects on the distributions of rare earth elements and selected first series transition elements. Proceedings, Fourth International Symposium on Water-Rock Interaction, Misasa, Japan, 29 Aug.-3 Sept., 48-49.

Bence, A. E., and Taylor, B. E., 1985. Rare earth element systematics of West Shasta Metavolcanic Rocks: Petrogenesis and hydrothermal alteration. Econ. Geol., 80:2164-2176.

Berndt, M. E., Seyfried, W. E., Jr, and Beck, J. W., 1988. Hydrothermal alteration processes at mid-ocean ridges: Experimental and theoretical constraints from $\mathrm{Ca}$ and $\mathrm{Sr}$ exchange reactions and $\mathrm{Sr}$ isotopic ratios. J. Geophys. Res., 93:4573-4583.

Bonnot-Courtois, C., 1981. Distribution des terres rares dans le depots hydrothermaux de la zone FAMOUS et des Galapagos comparision avec les sediments metalliferes. Mar. Geol., 39:1-14.

Bowers, T. S., Campbell, A. C., Measures, C. I., Spivack, A. J., Khadem, M., and Edmond, J. M., 1988. Chemical controls on the composition of vent fluids at $13^{\circ}-11^{\circ} \mathrm{N}$ and $21^{\circ} \mathrm{N}$, East Pacific Rise. J. Geophys. Res., 93:4522-4536.

Bruland, K. W., 1983. Trace elements in seawater. In Riley, J.P. and Chester, R., (Eds.), Chemical oceanography, Vol.8: London (Academic Press), 157-220.

Campbell, A. C., Palmer, M. R., Klinkhammer, G. P., Bowers, T. S., Edmond, J. M., Lawrence, J. R., Casey, J. F., Thompson,
G., Humphris, S., Rona, P., and Karson, J. A., 1988. Chemistry of hot springs on the Mid-Atlantic ridge: TAG and MARK Sites. Nature, 335:514-519.

De Baar, H. J., Bacon, N. P., and Brewer, 1983. Rare-earth distributions with a positive $\mathrm{Ce}$ anomaly in the Western North Atlantic Ocean. Nature, 301:324-327.

Duke, M.J.M. and Smith, A. D., 1987. Determination of REE in silicate rocks by neutron activation analysis and mass spectrometry. J. Radioanal. Nucl. Chem., 110:207-213.

Edmond, J. M., Measures, C., McDuff, R. E., Chan, L. J., Collier, R., Grant, B., Gordon, L. I., and Corliss, J. B., 1979. Ridge crest hydrothermal activity and the balances of the major and minor elements in the ocean: The Galapagos data. Earth Planet. Sci. Lett., 46:1-18.

Fleet, A. J., 1983. Hydrothermal and hydrogenous ferro-manganese deposits: Do they form a continuum? The rare earth element evidence. In Rona, P. A., Bostrom, K., Laubier, L., and Smith, K. L., Jr. (Eds.), Hydrothermal Processes at Seafloor Spreading Centers: New York (Plenum Press), 535-555.

Goldfarb, N. S., Converse, D. R., Holland, .. D., and Edmond, J. M., 1983. The genesis of hot spring deposits on the East Pacific Rise, $21^{\circ} \mathrm{N}$. In Ohmoto, H. and Skinner, B., (Eds.), The Kuroko and related volcanogenic massive sulfide deposits, Monogr. 5: Duluth, MN (Economic Geology Publishing), 184-197.

Haymon, R. M., 1983. Growth history of hydrothermal black smoker chimneys. Nature, 301:695-698.

Honnorez, J., Alt, J., Honnorez-Guerstein, B.-M., Laverne, C., Muehlenbachs, K., Ruiz, J., and Saltzman, F., 1985. Stockworklike sulfide mineralization in young oceanic crust: Deep Sea Drilling Project Hole 5048. In Anderson, R. M., Honnorez, J., Becker, K., et al., Init. Repts. DSDP, 83: Washington (U.S. Govt. Printing Office), 263-282.

Janecky, D. R. and Seyfried, W. E., 1984. Formation of massive sulfide deposits on oceanic ridge crests: Incremental reaction models for mixing between hydrothermal solutions and seawater. Geochim. Cosmochim. Acta, 48:2723-2738.

Machado, N., Brooks, C., and Hart, S. R., 1986. Determination of initial ${ }^{87} \mathrm{Sr} /{ }^{86} \mathrm{Sr}$ and ${ }^{143} \mathrm{Nd} /{ }^{144} \mathrm{Nd}$ ratios in primary minerals from mafic and ultramafic rocks: Experimental procedure and implications for the isotopic characteristics of the Archean mantle under the Abitibi greenstone belt, Canada. Geochim. Cosmochim. Acta, $50: 2335-2348$.

Michard, A., Albaréde, F., Michard, G., Minster, J. F., and Charlou, J. L., 1983. Rare-earth elements and uranium in high-temperature solutions from East Pacific Rise hydrothermal vent field $\left(13^{\circ} \mathrm{N}\right.$. Nature, 303:795-797.

Michard A., and Albaréde F., 1986. The REE content of some hydrothermal fluids. Chem. Geol., 55:51-60.

Morgan, J. W., and Wandless, G. A., 1980. Rare earth element distribution in some hydrothermal minerals: Evidence for crystallographic control. Geochim. Cosmochim. Acta, 44:973-980.

Ocean Drilling Program Leg 106 Scientific Party, 1986. Drilling the Snake Pit hydrothermal sulfide deposit on the Mid-Atlantic Ridge, lat $23^{\circ} 22^{\prime}$ N. Geology, 14:1004-1007.

Palmer, M. R., and Elderfield, H., 1985. Sr isotope composition of seawater over the past $75 \mathrm{Myr}$. Nature, 314:526-528. 
Rossman, G. R., Weis, D., and Wasserburg, G. J., 1987. Rb, Sr, Nd, and $\mathrm{Sm}$ concentrations in quartz. Geochim. Cosmochim. Acta, 51:2325-2329.

Seyfried, W. F., Jr., 1987. Experimental and theoretical constraints on hydrothermal alteration processes at mid ocean ridges. Ann. Rev. Earth Planet. Sci., 15:317-335.

Shipboard Scientific Party, 1988. Site 649. In Detrick, R., Honnorez, J., Bryan, W. B., Juteau, T., et al., Proc. ODP, Init. Repts., 106: College Station, TX (Ocean Drilling Program), 135-162.

Staudigel, H., Hart, S. R., and Richardson, S. H., 1981. Alteration of the oceanic crust: Processes and timing. Earth Planet. Sci. Lett., 52:311-327.

Styrt, M. M., Brackmann, A. J., Holland, H. D., Clark, B. C., Pisutha-Arnond, V., Eldridge, C. S., and Ohmoto, H., 1981. The mineralogy and isotopic composition of sulfur in hydrothermal sulfide/sulfate deposits on the East Pacific Rise, $21^{\circ} \mathrm{N}$ latitude, Earth Planet. Sci. Lett., 53:382-390.

Sverjensky, D. A., 1984. Europium redox equilibria in aqueous solution. Earth Planet. Sci. Lett., 67:70-78.

Thompson, G., Humphris, S. E., Schroeder, B., Sulanowska, M., and Rona, P. A., 1988. Active vents and massive sulfides at $26^{\circ} \mathrm{N}$ (TAG) and $23^{\circ} \mathrm{N}$ (Snake Pit) on the Mid-Atlantic Ridge. Can. Mineral., 26:697-711.

Tivey, M. K., and Delaney, J. R., 1986. Growth of large sulfide structures on the Endeavor segment of the Juan de Fuca Ridge. Earth Planet. Sci. Lett., 77:303-317.
Vidal, P., and Clauer, N., 1981. Pb and $\mathrm{Sr}$ isotopic systematics of some basalts and sulfides from the East Pacific Rise at $21^{\circ} \mathrm{N}$ (project RITA). Earth Planet. Sci. Lett., 55:237-246.

Von Damm, K. L., 1988. Systematics of and postulated controls on submarine hydrothermal solution chemistry. J. Geophys. Res., 93:4551-4561.

Von Damm, K. L., and Bischoff, J. L., 1987. Chemistry of hydrothermal solutions from the southern Juan de Fuca Ridge. $J$. Geophys. Res., 92:11334-11346.

Von Damm, K. L., Edmond, J. M., Grant, B., Measures, C. I., Walden, B., and Weiss, R. F., 1985. Chemistry of hydrothermal solutions at $21^{\circ} \mathrm{N}$, East Pacific Rise. Geochim. Cosmochim. Acta, 49:2197-2220.

Whitford, D. J., Korsch, M. J., Porritt, P. M., and Craven, S. J., 1988. Rare-earth element mobility around the volcanogenic polymetallic massive sulfide deposit at Que River, Tasmania, Australia. Chem. Geol., 68:105-119.

Woodruff, L. G., and Shanks, W. C., 1988. Sulfur isotope study of chimney minerals and vent fluids from $21^{\circ} \mathrm{N}$, East Pacific Rise: Hydrothermal sulfur sources and disequilibrium sulfate reduction. J. Geophys. Res., 93:4562-4572.

Date of initial receipt: 12 July 1988

Date of acceptance: 1 May 1989

Ms 106/109B-164 